\title{
IAMJ
}

INTERNATIONAL

AYURVEDIC

MEDICAL JOURNAL

\section{INSIGHTS INTO THE CONCEPT OF TRIVIDHA BODHYA SANGRAHA: A CONCEPTUAL REVIEW}

\author{
Samantri Jyothi ${ }^{1}$, Shreevathsa ${ }^{2}$, Bharath $\mathrm{V}^{3}$ \\ ${ }^{1} 2^{\text {nd }}$ Year PG Scholar, Dept of Ayurveda Samhita Siddhanta, GAMC, Mysuru, Karnataka, India \\ ${ }^{2}$ Professor \& Head, Dept of Ayurveda Samhita Siddhanta, GAMC, Mysuru, Karnataka, India \\ ${ }^{3}$ Final Year PG Scholar, Dept of Ayurveda Samhita Siddhanta, GAMC, Mysuru, Karnataka, India
}

Corresponding Author: samantrij@gmail.com

\section{https://doi.org/10.46607/iamj1709122021}

(Published Online: December 2021)

Open Access

(C) International Ayurvedic Medical Journal, India

Article Received: 04/11//2021 - Peer Reviewed: 29/11/2021 - Accepted for Publication 30/11/2021

\section{Check for updates}

\begin{abstract}
Ayurveda being the Shashwatha Vijnana deals with many concepts which are applicable at all times. As the Prayojana of the Science is maintaining the health of healthy and curing the diseases of diseased person; in order to understand the disease, many concepts have been described among which Trividha Bodhya Sangraha is the prime one. This particular concept has been dealt under Rogachatushka of Charaka Samhita while explaining about Asankhyeyatva of Vyadhi. It includes Vikara Prakruthi, Adhishtana and Samutthana Vishesha. In classical texts there is an elaborative description of many diseases; but as time passes a new variety of pathological presentations are manifesting which are not exactly similar to those mentioned in classics. There might be different Nidanas, different dosha involvement, different Adhisthana in the body and different Lakshanas. In such cases, a proper understanding of the entire condition is necessary to plan management protocol. Prior to that, there is the necessity of complete knowledge about Trividha Bodhya Sangraha i.e. their scope, application and limitations. Therefore, the present work is attempting for the same which will be helpful in understanding the concept and application of the same in practice.
\end{abstract}

Keywords: Trividha Bodhya Sangraha, Vikara Prakruthi, Adhishtana, Samutthana Vishesha, Anukta Vyadhi, Aparisankhya Vyadhi. 


\section{INTRODUCTION}

Suthrasthana of Charaka Samhita is said to be the Shirah of Samhita which is logically divided into 7 chatushka and 2 Sangrahadhyaya. Rogachatushka is one of them which acts as an introductory part of Nidana sthana and also deals with important concepts of Ayurveda.

Though there are various classifications of Vyadhi in Ayurveda, at many contexts or as a concluding statement, Acharya has declared about Aparisankhyeyatva of Vyadhi. Among various Sthanas of Samhita. Acharya Charaka has been explained many aspects such as Nidana, Purvarupa, Roopa Samprapti, Upashaya-Anupashaya, Sadhyasadhyata, Chikithsa, Varjya Rogi etc. pertaining to particular diseases. Still, guidance can be seen about some general concepts/principles by which undescribed conditions could be understood.

It is the beauty of Charaka Samhitha to give the guidelines of medical knowledge in the form of Sutras which are not only mere Shlokas, explaining the lengthy concepts in short, but also act as seeds. These seeds act as formulae for new concepts and practical applications. Trividha bodhya sangraha is one such concept dealt in Rogachatushka under Trishothiya Adhyaya ${ }^{\text {. It forms }}$ the basis for identification, understanding and planning for the management of any pathological condition including Anukta Vyadhi \& novel pathologies.

\section{MATERIALS AND METHODS:}

- The primary source of data is from Charaka samhitha Moola Grantha

- Concepts are compiled from classical texts, other textbooks and various research journals. Further discussion has been done on the conceptual part to provide insights in order to understand the concept properly.

\section{OBJECTIVES:}

- To analyze the concept of Trividha Bodhya Sangraha through literary review

- To analyze the application of Trividha Bodhya Sangraha with the examples of Atisaara, Shotha and Kushtha diseases

\section{Review of Literature:}

\section{Trishothiya adhyaya ${ }^{2}$}

In this context, it is mentioned that nomenclature of every condition is not possible as the same Dosha when vitiated can cause various disorders based on some particular factors such as Samutthana Vishesha and Sthanantaragata. In the commentary, one example has been given - vitiated Dosha when lodges in Kanta can cause Kasa, Aruchi, Kantodhwamsa etc. Hence every condition should be analyzed by considering Vikara Prakruthi, Adhishtana and Samutthana Vishesha which are termed as Trividha Bodhya Sangraha in order to treat a particular pathology.

\section{Ashtodariya adhyaya ${ }^{3}$}

The same Tridosha when vitiated based on Sthana, Samsthana and Prakruthi vishesha will cause all the diseases including Anukta Vyadhi.

In the commentary, Sthana refers to Rasadi and Basthyadi; Samsthana refers to Lakshana of Vyadhi and Prakruthi Vishesha refers to the Karana for the manifestation of Disease.

\section{Maharogadhyaya ${ }^{4}$}

After the explanation of Nanathmaja Vikara, Acharya has dealt with Aparisankhyeyatva of Vyadhi which is due to Aparisankhyeyatva of Prakruthi (aetiology), Adhishtana (region) and Linga (signs \& symptoms). Along with this, Ayatana has been considered which means external causes like Dushta Ahara, Achara according to Acharya Chakrapani and Vishesha Sthana of Dosha i.e., Pakvashaya etc according to Acharya Gangadhara ${ }^{5}$.

\section{Roganika vimana adhyaya ${ }^{6}$}

Here also, while providing reasoning for innumerable diseases, Acharya has mentioned Prakopana Vishesha (Nidana), Dushya Vishesha (Adhishtana) and Vikara Vishesha (Lakshana).

In all the above instances Trividha Bodhya Sangraha has been reflected and thus the importance of the same can be inferred. 


\section{DISCUSSION}

\section{Discussion on Trividha Bodhya Sangraha:}

\section{Samutthana Vishesha:}

This refers to the Vishesha Karana for a Particular disease. Dosha is considered as Samavayi Karana for the manifestation of any disease. At the same time, Agni and Ama will also play an important role. Therefore, under the heading of Vikara Prakruthi, Dosha, Agni and Ama can be included.

A. Dosha: Tridosha is the principal factor for health and disease. ${ }^{7}$ Roga cannot manifest without the involvement of Dosha and Anukta Vyadhi should be understood with the help of Dosha Lakshana. ${ }^{8}$ Dosha are the only reason for the pathological manifestations always. ${ }^{9}$ In Kriyakala, Sanchaya is the first stage where there will be an accumulation of Dosha in their root places which is the beginning of disease but until Sthana Samshraya it cannot be considered as Vyadhi, at present scenario due to unawareness of such things, it can be considered. Hence Dosha will be the prime factors under the heading of Samutthana Vishesha.

B. Agni: Though Dosha is a basic factor for disease manifestation, their state will be depending on the state of $A g n i^{10}$. Due to the vitiation of Agni, there will be manifestation of various disorders in the body ${ }^{11}$. Agni, situated in Pittadosha is responsible for the normalcy and abnormal conditions of the body when it is in a normal or vitiated state respectively ${ }^{12}$. Classification of Agni is based on the Dosha itself. Therefore, both the factors influence each other in all instances. Hence both can be considered as the prime factors for both health and disease.

C. Ama: Ama produced due to Mandagni when amalgamates with Dosha and Dushya which can be termed as Sama is the aetiology for all the diseases ${ }^{13}$. Though in the commentary, Vikara Prakruhi has been referred to as Vatadi Dosha, Agni and Ama play a significant role in the manifestation of any Vyadhi and Vatadi merely refers to the entities which form the Pratyasanna Karana for Vyadhyutpatti.

Beyond these, there exists Trividha Hetu, which are the root cause for any Vikruthi;

- Asathmyendriyarta

- Prajnaparadha
- Parinama $^{14}$

Janapadodhwamsa is a time where the basic principles dealt in classics will be having more application; especially those mentioned under Roga Pariksha as there will be an occurrence of entirely new presentation of pathology which cannot be elicited easily. For that also Prajnaparadha is said to be Yoni (root cause) ${ }^{15}$.

\section{Adhishtana:}

The site of manifestation of any pathological condition can be termed as Adhishtana. i.e., Rasadi Dhatu, Basthyadi Ashaya/Avayava. For example, 'Uru' sthambha, 'Rakta'yoni etc. diseases will not only change with the change of Adhishtana, in the same region there can also be a manifestation of various disorders. Ex: vitiated Dosha when lodges in Gala can cause Kasa, Aruch, Swarabheda, Kantodwamsa etc. ${ }^{16}$.

In the $20^{\text {th }}$ chapter of Charaka Samhita Suthrasthana, 'Ayatana' has been mentioned along with Vikara Prakruthi, Adhishtana and Samutthana, which signifies the Mula/Vishesha Sthana of Tridosha, that to Pakwashaya and Amashaya.

Review work on Adhishtana alone is needed to clarify whether Adhishtana includes Udbhava sthana and sanchara sthana also as it is especially indicating 'Vyaktasthana' of any disorder.

\section{Vikara Prakruthi:}

Vikara Prakruthi is the signs and symptoms of a particular pathological condition. Though, irrespective of the disease manifested, the signs and symptoms should be presented as per the Dosha involved, each disease will be having its own specific Lakshana which will differentiate it from others. And also, the management will be based on the presentation of Dosha itself. Most of the time the Chikithsa encounters Lakshanika type as eliciting the Nidana could be difficult in many cases. For better understanding of the present concept, the following example will be considered:

1) Samutthana Vishesha (Purusha Niyata): Atisara

2) Adhishtana (Sthana Niyata): Shotha

3) Vikara Prakruthi (vyadhi Niyata): Kushta

1) Samutthana Vishesha (Purusha Niyata): Atisara

"Prati Purusha Siddhanta is the very basic concept of Chikithsa Aspects of Ayurveda. For the manifestation of any disease, Nidana is specific. In the context of 
'Atisara Chikithsitam' Acharya Charaka has given utmost importance to Prakruthi and dealt Nidana accordingly. Atisara is not only a disease, rather it is $\mathrm{Ni}$ dana/Purvarupa/Rupa/Upadrava/Arishta lakshana in most of the diseases, which indicates its varied intensity.
As Dosha, Agni and Ama are the significant factors among Samutthana Vishesha, all the 3 seems to be appreciated well in case of Atisara. Hence this example has been taken for understanding.

Table 1: is depicting the Nidana of Atisara.

\begin{tabular}{|c|c|c|}
\hline Deha Prakruth & Samutthana Vishesha & Mechanism \\
\hline Vata & $\begin{array}{l}\text { Excessive indulgence in Vata, Atapa and Vyayama. } \\
\text { Ruksha-Alpa-Pramithashana } \\
\text { Tikshna madya } \\
\text { Nithya vyavaya } \\
\text { Udavarta }\end{array}$ & $\begin{array}{l}\text { Vata vruddhi-agnimandya } \\
\text { Ruksha-drags Dravamsha from Dravadhatu into } \\
\text { the Koshta } \\
\text { Chala guna - Atisarana of Pureesha. }\end{array}$ \\
\hline Pitta & $\begin{array}{l}\text { Excessive intake of Amla, Lavana, Katu, Tikshna } \\
\text { Kshara, Ushna food articles. } \\
\text { Excessive indulgence in Agni Atapa, Suryatapa, } \\
\text { Maruta } \\
\text { Excess krodha and irshya }\end{array}$ & $\begin{array}{l}\text { Pitta Dravaguna Vruddhi-Agnimandya } \\
\text { Ishath Ushna Guna along with Drava, Tikshna, } \\
\text { Sara- liquefies Pureesha } \\
\text { Sara Guna - Atisarana of Pureesha. }\end{array}$ \\
\hline Kapha & $\begin{array}{l}\text { Excess intake of Guru, Madhura, Snigdha food arti- } \\
\text { cles } \\
\text { Achintana after taken excess food } \\
\text { Divaswapna, Alasya. }\end{array}$ & $\begin{array}{l}\text { Soumya Guna - Agnimandya } \\
\text { Sheeta Snigdha Guna - liquefies Pureesha } \\
\text { Drava, Snigdha, Shita Guna - Atisarana of Pu- } \\
\text { reesha }\end{array}$ \\
\hline
\end{tabular}

\section{2) Adhishtana (Sthana Niyata): Shotha}

Shotha is generally understood as 'swelling'. Trishothiya Adhyaya of Charaka Samhita Suthrasthana is the context where for the first time the concept of Trividha Bodhya Sangraha has been mentioned. The same sign at different regions of the body attains different names and also there will be involvement of different Nidana and Lakshana, but Adhishtana seems to be important in this case.

Table 2: is depicting Adhishtna of various Shotha.

\begin{tabular}{|l|l|l|}
\hline Shotha & Predominant dosha & Adhishtana \\
\hline Upajihvika & Kapha & Jihvamula \\
\hline Galashundika & Kapha & Gala \\
\hline Galaganda & Kapha & Galaparshwa \\
\hline Galagraha & Kapha & Anrgala \\
\hline Visarpa & Pitta & Twak \\
\hline Pidaka & Pitta & Twak \\
\hline Tilaka, piplu, vyanga, nilika & Pitta & Twak \\
\hline Shankhaka & Pitta & Shankhapradesha \\
\hline Karnamula shotha & Pitta & Karnamula \\
\hline Plihavruddhi & Vata & Pliha \\
\hline Gulma & Vata & Basthi, hrudaya, nabhi, both parshwa. \\
\hline Vruddhi roga & Vata & Vankshana, vrushana \\
\hline Udara & Vata & Udara \\
\hline Anaha & Vata & Kukshi \\
\hline Rohini & Tridosha & Gala \\
\hline
\end{tabular}




\section{3) Vikara Prakruthi (Vyadhi Niyata): Kushta}

Kushta has been considered as Mahagada by all the Acharya. The condition has been classified based on the Severity and predominant Dosha involved, at the end, Acharya has said that there are innumerable Kushta. This explores a new door for skin diseases which are arising constantly due to many reasons and naming of which is a difficult job and hence they are treated based on the Lakshana they present with. Lakshana seems to be the important aspect in case of Kushta as there are innumerable reasons and the Adhishtana varies from particular area to all over the body. The symptoms are guides for understanding the Dosha involved and also for the planning of management protocol.

Table 3: is depicting signs and symptoms of various Kushta.

\begin{tabular}{|c|c|}
\hline Kushta & Samutthana Vishesha \\
\hline Kapala & $\begin{array}{l}\text { Signs - krushna aruna varsna, ruksha-parusha-tanu, vishamakruthi } \\
\text { Symptoms - todabahula. }\end{array}$ \\
\hline Udumbara & $\begin{array}{l}\text { Signs - raga, pinjara loma, udumbara phala sadrusha } \\
\text { Symptoms - daha, kandu, ruja }\end{array}$ \\
\hline Mandala & Signs - shwata-rakta varna, sthira, snigdha, utsanna mandala \\
\hline Rushyajihva & $\begin{array}{l}\text { Signs - karkasha, raktaparyanta-antam shyava varna, rushyajihva sadrusha } \\
\text { Symptoms - vedana }\end{array}$ \\
\hline Pundarika & $\begin{array}{l}\text { Signs - shweta varna and raktaparyanta, pundarika dala sadrusha, utseda } \\
\text { Symptoms - daha }\end{array}$ \\
\hline Sidhma & Signs - shweta-tamra varna, raja vimunchana, alabupushpa varna \\
\hline Kakanaka & $\begin{array}{l}\text { Signs - kakanantika varna } \\
\text { Symptoms - apaka, tivravedana, tridosha linga. }\end{array}$ \\
\hline Ekakushta & Aswedana, mahavasthu, mathsyashakalavath \\
\hline Charmakhya & Bahala and hasthicharmavath \\
\hline Kitibha & Shyava varna, khina-khara sparsha \\
\hline Vipadika & Pani pada sphutana, tivravedana \\
\hline Alasaka & Kandu, ragayukta pidaka \\
\hline Dadru & Kandu ragayuykta pidaka with mandolotsanna \\
\hline Charmadala & Kandu, sphota, ruja, sparshasahishnuta. \\
\hline Pama & Shweta aruna shyava varna, kanduyukta pidaka \\
\hline Visphota & Tanutwacha, sphota, shweta aruna varna \\
\hline Shataru & Bahuvrana, rakta shyava varna, daha, ruja. \\
\hline Vicharchika & Kanduyukta pidaka, shyava varna, bahusrava. \\
\hline
\end{tabular}

\section{Discussion on the concept of Trividha Bodhya San- graha:}

1. Concept of Trividha Bodhya Sangraha in Suthrasthana-significance:

Suthrasthana is said to be Shira of Charaka Samhita and the Chatushka are having exclusive information they are meant to $b^{16}$. Also, it deals with the concepts which are applicable and helpful in understanding the whole Samhita. The concept of Trividha Bodhya Sangraha has been described first in the Rogachatushka under Trishothiya Adhyaya which has been quoted again in the $19^{\text {th }} \& 20^{\text {th }}$ chapter in the context where 'Aparisankhyeyata 'of Roga come into the picture. In order to understand any pathological condition, the very three basic factors are Nidana, Adhishtana \& Lakshana. Rogachatushka is the introductory part of $\mathrm{Ni}$ dana Sthana, or it is the beginning of Nidana Sthana as there is a description of various diseases. It should provide a strong basis and basic principles for the understanding of that subject matter for which it is intended. That is the reason the Concept of Trividha Bodhya Sangraha has been dealt with here. 
2. Exclusive information has been provided about Dosha in Roga Chatushka itself which is specifically helpful for the way of Chikithsa.
Though in other chapters of Suthrasthana, information regarding Dosha has been dealt, in Rogachatushka, it is evident.

Table 4: is depicting information about Dosha in Rogachatushka.

\begin{tabular}{|l|l|}
\hline Chapter & Concept \\
\hline Kiyantha shirasiya & Dosha gati \\
\hline Trishothiya & Prakrutha \& Vaikrutha Dosha Karma \\
\hline Ashtoudariya & Integrity of Dosha in Nijavikara \\
\hline Maharogadhyaya & Prakrutha Doshasthana \\
& Athmalakshana; Doshopakrama \\
\hline
\end{tabular}

3. Even after describing the Concept of Trividha Bodhya Sangraha, Nidana Panchaka have been dealt in Nidana Sthana. Whether they are extended information about the same?

As the entire Ayurveda is embedded in the form of Trisuthra, all the information regarding the understanding of the disease is framed under Trividha Bodhya Sangraha. Samutthana Vishesha refers to the state of Vadadi Dosha and Agni in the manifestation of any disease. They include all the Samanya and Vishesha Nidana contributing to the disease. Adhishtana refers to the region of the body where a particular disease exhibits itself. It may include the place of Sthana Samshraya, Udbhava Sthana, Sanchara Sthana and Vyakta Sthana at its core. For the understanding purpose, it has been simplified as Adhishtana, the region where Vyadhi is expressed. Vikara Prakruthi is Lakshana of a particular disease and Purvarupa can also be considered here as they are reflecting the Lakshana of fore coming condition. Thus, it can be said that Nidana Panchaka is the extended version of Trividha Bodhya Sangraha.

4. Scope of the Concept of Trividha Bodhya Sangraha in Anukta Vyadhi.

It is more applicable for Anukta Vyadhi itself. All the diseases that can manifest in living beings will never trespass the Dosha thus, even Anukta Vyadhi can be understood with proper knowledge of aetiology, location and symptoms of particular pathological condition ${ }^{17}$.

5. Even the nomenclature of diseases is said to be Vyavaharartha, many are having a particular name. For illustration, some of the pathological presentations have been given. They are for both purposes ie, understanding the condition and planning of treatment. There are innumerable Shotha that can manifest due to different Sthana, Dushya, Akruthi, Nama etc but only a few have been explained for the guidance of a physician. With that instance, one should incorporate such principles in order to treat the condition ${ }^{18}$.

6. Whether the Concept of Trividha Bodhya Sangraha is enough for the understanding of Vyadhi and planning of Treatment?

As Vikara Prakruthi includes the state of Dosha and Agni, Adhishtana includes Sthana at which Doshadushyasammurchana takes place and Vyadhi manifests and Samutthana Vishesha includes all the signs and symptoms of a Vyadhi. Understanding of these is enough for a thorough knowledge of any pathology. In Ayurveda, there are Upakrama for Dosha, Dhatu Poshana/Prasadana krama, Mala Shodhana. Though there are Vyadhi Prathyanika Chikithsa /Aushadha exists, those, in turn, act upon Dosha itself as it is said that - how the diseases will not trespass the Dosha, in the same way, Upakrama for the same will not extend beyond Shadupakrama ${ }^{19}$ (Cha. Su. 22/43). Hetu Prathyanika, Vyadhi Prathyanika, Samprapti Vighatana and Lakshanika Chikithsa. All are concentrating towards one or the other entity of Trividha Bodhya Sangraha.

7. Among Trisuthra, Hetu and Linga are included under Trivida Bodhya Sangraha. Whether it is indicating the significance of the same?

Charaka Samhita being Kayachikithsa Pradhana Tantra, has its whole information in the seed Trisuthra. i.e., Hetu, Linga \& Aushadha. And former two are part of Trivida Bodhya Sangraha. Of course, it is indicating the 
importance of the same by stressing the point that $\mathrm{Ni}$ dana and Lakshana are the key factors for the understanding of Health and Disease.

\section{Scope of Trividha Bodhya Sangraha:}

Already eradicated diseases and those which have not yet manifested can also be understood based on the present concept. Polio was not mentioned in classics as exactly the condition was. But the virus, incubation period, affected part of the body, signs and symptoms have been elicited after its manifestation. And also, the treatment had been planned based on these aspects only.

In the case of COVID-19 also, the same theory had been applied.

Samutthana: Dosha Prakopa due to the entry of virus Adhishtana: earlier it was lungs, later along with lungs GIT involvement had been elicited.

Prakruthi: cold, dry cough, fever, breathlessness etc.

Thus, it can be said that every pathological condition which has not been explained in the classics can also be understood in its entirety with the help of Trividha Bodhya Sangraha.

9. Application of the concept in further Sthana of Samhita.

The concept has been exclusively extended in Vimana sthana (Trividhakuksheeya adhyaya), Nidana sthana, Chikithsa sthana and Siddhisthana also.

10. References of the concept in other Samhitha.

Direct references are not there, but while describing Anukta Vyadhi or Aparisankhyeyata of Vyadhi, various factors have been mentioned among which these three have also been included.

\section{CONCLUSION}

The concepts told in Ayurveda are Shashwatha at their existence and application. Irrespective of the time, place, change of anything, the concepts stands valid. Therefore, the importance of basic principles could not be measured as they are always beyond perception. The present concept is one such concept that guides for the understanding of the disease which has been explained in classics and also which has not been mentioned, planning of their treatment protocol and thus helps in achieving the Prayojana of Ayurveda.

\section{REFERENCES}

1. Vaidya YT Acharya, editor. Charaka Samhitha by Agnivesha with Ayurveda Deepika Teeka. Choukhamba Surabharathi Prakashan, Varanasi, 2014. Pg.no:108

2. Vaidya YT Acharya, editor. Charaka Samhitha by Agnivesha with Ayurveda Deepika Teeka. Choukhamba Surabharathi Prakashan, Varanasi, 2014. Pg.no:108

3. Vaidya YT Acharya, editor. Charaka Samhitha by Agnivesha with Ayurveda Deepika Teeka. Choukhamba Surabharathi Prakashan, Varanasi, 2014. Pg.no:111

4. Vaidya YT Acharya, editor. Charaka Samhitha by Agnivesha with Ayurveda Deepika Teeka. Choukhamba Surabharathi Prakashan, Varanasi, 2014. Pg.no:112

5. Vaidya YT Acharya, editor. Charaka Samhitha by Agnivesha with Ayurveda Deepika Teeka. Choukhamba Surabharathi Prakashan, Varanasi, 2014. Pg.no:252

6. Vaidya YT Acharya, editor. Charaka Samhitha by Agnivesha with Ayurveda Deepika Teeka. Choukhamba Surabharathi Prakashan, Varanasi, 2014. Pg.no:112

7. Pt. Hari Sadashiva Shastri Paradakara, Vagbhata, Astanga Hrdaya, Sarvanga sundara commentary of Arunadatta \& Ayurveda rasayana commentary of Hemadri, Reprint Ed, Chaukhambha Surabharati Prakashan, Varanasi 2007, Pg no:14

8. Vaidya YT Acharya, editor. Charaka Samhitha by Agnivesha with Ayurveda Deepika Teeka. Choukhamba Surabharathi Prakashan, Varanasi, 2014. Pg.no:111

9. Pt. Hari Sadashiva Shastri Paradakara, Vagbhata, Astanga Hrdaya, Sarvanga sundara commentary of Arunadatta \& Ayurveda rasayana commentary of Hemadri, Reprint Ed, Chaukhambha Surabharati Prakashan, Varanasi 2007, Pg no:197

10. Vaidya YT Acharya, editor. Charaka Samhitha by Agnivesha with Ayurveda Deepika Teeka. Choukhamba Surabharathi Prakashan, Varanasi, 2014. Pg.no:442

11. Vaidya YT Acharya, editor. Charaka Samhitha by Agnivesha with Ayurveda Deepika Teeka. Choukhamba Surabharathi Prakashan, Varanasi, 2014. Pg.no:491

12. Vaidya YT Acharya, editor. Charaka Samhitha by Agnivesha with Ayurveda Deepika Teeka. Choukhamba Surabharathi Prakashan, Varanasi, 2014. Pg.no:80

13. Pt. Hari Sadashiva Shastri Paradakara, Vagbhata, Astanga Hrdaya, Sarvanga sundara commentary of Arunadatta \& Ayurveda rasayana commentary of Hemadri, Reprint Ed, Chaukhambha Surabharati Prakashan, Varanasi 2007, Pg no:216 
14. Vaidya YT Acharya, editor. Charaka Samhitha by Agnivesha with Ayurveda Deepika Teeka. Choukhamba Surabharathi Prakashan, Varanasi, 2014. Pg.no:14

15. Vaidya YT Acharya, editor. Charaka Samhitha by Agnivesha with Ayurveda Deepika Teeka. Choukhamba Surabharathi Prakashan, Varanasi, 2014. Pg.no:242

16. Vaidya YT Acharya, editor. Charaka Samhitha by Agnivesha with Ayurveda Deepika Teeka. Choukhamba Surabharathi Prakashan, Varanasi, 2014. Pg.no:108

17. Vaidya YT Acharya, editor. Charaka Samhitha by Agnivesha with Ayurveda Deepika Teeka. Choukhamba Surabharathi Prakashan, Varanasi, 2014. Pg.no:190

18. Vaidya YT Acharya, editor. Charaka Samhitha by Agnivesha with Ayurveda Deepika Teeka. Choukhamba Surabharathi Prakashan, Varanasi, 2014. Pg.no:111

19. Vaidya YT Acharya, editor. Charaka Samhitha by Agnivesha with Ayurveda Deepika Teeka. Choukhamba Surabharathi Prakashan, Varanasi, 2014. Pg.no:488

20. Vaidya YT Acharya, editor. Charaka Samhitha by Agnivesha with Ayurveda Deepika Teeka. Choukhamba Surabharathi Prakashan, Varanasi, 2014. Pg.no:123

\section{Source of Support: Nil \\ Conflict of Interest: None Declared}

How to cite this URL: Samantri Jyothi et al: Insights Into The Concept Of Trividha Bodhya Sangraha: A Conceptual Review. International Ayurvedic Medical Journal \{online\} 2021 \{cited December 2021\} Available from: http://www.iamj.in/posts/images/upload/3026 3033.pdf 